\title{
TÉCNICA E NATUREZA NO DESENVOLVIMENTO DO "AGRONEGÓCIO"1
}

\author{
Valter Lúcio de Oliveira* \\ Ève Anne Bühler**
}

\begin{abstract}
Se, em diversos setores da economia, a lógica de acumulação capitalista se efetivou sem enfrentar maiores obstáculos, na agricultura, ao contrário, importantes aspectos relacionados a seu caráter natural lhe impuseram significativas limitações. Até a década de 1970, por exemplo, o cerrado não era considerado apto para a prática da agricultura do tipo que hoje é ali praticada. Da mesma forma, o avanço no campo das biotecnologias já superou e tem prometido a superação de algumas das limitações que ainda persistem. A partir de tais considerações, pretendemos caracterizar a agricultura desenvolvida nos cerrados nordestinos e analisar a relação que ela estabelece com a natureza a partir da técnica e da acumulação capitalista. Percebe-se, nessas regiões, a consolidação de uma agricultura neoliberal em que a comodificação da natureza é uma dimensão saliente no processo de incorporação de novas fronteiras agrícolas. Ela se apoia sobre o discurso e a prática tecnicista dos agentes do setor, que visam a um maior domínio dos processos produtivos. Nessa dinâmica, o desprezo pelos ecossistemas nativos e o controle da natureza a partir da técnica são, ainda, elementos fundamentais no discurso de atração de colonos e investidores no setor. Esses aspectos serão tratados tomando-se como base pesquisa empírica desenvolvida desde 2011 na região conhecida como MATOPIBA (Maranhão, Tocantins, Piauí e Bahia).

Palavras-chave: Agronegócio. Cerrados Nordestinos. Commodificação da Natureza. Agricultura Empresarial.
\end{abstract}

\section{INTRODUÇÃO}

O tipo de agricultura desenvolvido em certas áreas do cerrado brasileiro promoveu transformações acentuadas em diversas dimensões da vida local e regional. Consorciando uma série de elementos discursivos a algumas propriedades geográficas e técnicas, a "agriculturização" do cerrado atraiu levas de migrantes que impuseram novas formas de uso da terra. Esse processo, que, na região do Oeste da Bahia, e, mais amplamente, nos cerrados nordestinos, teve seu início na década de 1980, segue produzindo dinâmicas que alimentam transformações nas formas de relacionamento entre sociedade e natureza.

\footnotetext{
* Universidade Federal Fluminense. Departamento de Sociologia e Metodologia das Ciências Sociais.

Rua Professor Marcos Waldemar de Freitas Reis. campus Gragoatá. Bloco O, sala 305. São Domingos. Cep: 24210-201. Niterói - Rio de Janeiro - Brasil. valteroliveira@id.uff.br

${ }^{\star *}$ Universidade Federal do Rio de Janeiro. Departamento de Geografia.

Rua: Athos da Silveira Ramos, n. 274, G-025. Cidade Universitária. Departamento de Geografia/IGEO. Cep: 21941-916. Rio de Janeiro - Rio de Janeiro - Brasil. eve.buhler@gmail.com

${ }^{1}$ Este artigo foi desenvolvido a partir de pesquisa financiada com recursos do CNPq e a partir do convênio CAPESCOFECUB.
}

Se, por um lado, grande parte do que se promoveu, nessas regiões, já está assimilado ao cotidiano social das localidades e, portanto, não há novidade quanto à "vocação" da região para o "agronegócio" e nem surpresa quanto à fisionomia e os nomes europeus dos sulistas que ali se instalaram, por outro lado, essa aparente "estabilidade social" poderia ocultar determinados agentes cuja presença e identificação é bem menos evidente. São agentes menos integrados à dinâmica que caracteriza a sociabilidade local, além de serem promotores de negócios agrícolas irredutíveis aos processos já existentes na região. Trata-se de agentes que quase não estabelecem laços sociais com o local, mas que encontraram, ali, as condições adequadas a seus investimentos. Na origem da "colonização" dessa região, o discurso dos que chegaram remetia a um ideal de "aventureiros e desbravadores", "heróis" que enfrentaram e superaram toda sorte de dificuldades e que construíram uma região dotada de muitos dos atributos característicos do lugar de origem ao qual ainda estão fortemente lastreados, atualmente, esses novos agentes produzem uma inserção premida pela racionalidade que in- 
forma as ações de qualquer outro investidor capitalista em busca da melhor atividade e localidade para reproduzir seu capital.

Este artigo visa a compreender a dinâmica desse processo, colocando acento nas mudanças identificadas a partir dos primeiros movimentos de colonização agrícola promovidos pelos sulistas até o período mais recente, marcado pela instalação de grandes empresas do agronegócio de origem social e geográfica mais diversa. Pretende-se apontar as principais características que dão os contornos da racionalidade que informa o desenvolvimento dessa forma de se fazer agricultura, focando nos discursos que visam a consolidar o cerrado nordestino como uma região atrativa e favorável para a agricultura intensiva e capitalista. ${ }^{2} E$ E recorrente, nesse sentido, a indicação, por parte dos agentes envolvidos, de que elementos da natureza e a questão técnica são fundamentais para o que se efetiva nessas regiões.

O eixo norteador da análise está apoiado em um tripé conceitual que tem, em seus vértices, a questão da natureza, a questão da técnica e os processos de territorialização. É dizer que esses diversos agentes sociais produziram uma região na qual o cerrado é representado como um espaço e bioma pertinente para o tipo de atividade que ali tem sido desenvolvido, considerando, ao mesmo tempo, que a atuação e a transformação desse (nesse) espaço só podem ser efetivadas a partir de um modelo intensivo em tecnologia e a partir das lutas sociais e simbólicas pela atribuição de sentido a esse espaço.

As questões aqui introduzidas serão analisadas nas duas partes que compõem este artigo além da breve contextualização inicial. A primeira parte tratará das peculiaridades da atividade agrícola no capitalismo e do tipo de agricultura desenvolvido na região pesquisada, sugerindo uma tipologia acerca do perfil de produtores ali atuantes. Na segunda parte, será analisada a

${ }^{2}$ Esse tipo de agricultura vem sendo denominada de "Agricultura empresarial” (Guibert; Bühler; Requier-Desjardins, 2015), "Agricultura corporativa” (Batista; Inácio, 2011) ou "Agricultura de firma" (Hervieu; Purseigle, 2013). A designaremos aqui de agricultura empresarial. centralidade dos recursos naturais no desenvolvimento do agronegócio a partir do conceito de "commodificação da natureza" e da dinâmica de neoliberalização da fronteira agrícola.

Essas análises estão baseadas em pesquisa empírica objetivada ao longo de três temporadas de trabalho de campo realizadas nos meses de setembro de 2011, fevereiro de 2012 e outubro de 2014. Nessas ocasiões, realizamos entrevistas com agricultores, empresários, técnicos, políticos e funcionários públicos; participamos de eventos públicos, como dia de campo, eventos sociais e políticos. Além disso, percorremos centenas de quilômetros entre os municípios de Luis Eduardo Magalhães (BA) e Bom Jesus (PI) para apreender elementos próprios da dinâmica territorial da região.

\section{BREVE CONTEXTUALIZAÇÃO}

O processo brevemente exposto até aqui, encontrou, na região do Oeste da Bahia (e, mais amplamente, a região denominada MATOPIBA - Maranhão, Tocantins, Piauí, Bahia), um local adequado para se concretizar. O MATOPIBA se tornou uma região de investimento dos "antigos" produtores e dos novos investidores agrícolas, contribuindo para consolidação de um modelo produtivo liderado por médios e grandes estabelecimentos. Luis Eduardo Magalhães (LEM) e Barreiras, principais municípios do Oeste Baiano, ${ }^{3}$ são considerados referências para um "agronegócio" em processo de expansão espacial. Denise Elias irá definir LEM como uma "Cidade do Agronegócio", inspirada no que Milton Santos chamou de "Cidades do Campo", em consideração ao fato de estarem amplamente condicionadas pela dinâmica de tal setor econômico (Elias, 2006). LEM foi emancipada de Barreiras em março de 2000, depois de cerca de aproximadamente vinte anos de instalação progressiva de agricultores

\footnotetext{
${ }^{3}$ Esta região conta com um total de 23 municípios. Dos outros estados destacam-se Bom Jesus e Uruçuí no Piauí, Balsas na Maranhão e Araguaína no Tocantins.
} 
de médio e grande porte, especializados na produção de commodities agrícolas e usando técnicas e tecnologias das mais recentes. Desde então, não tem cessado seu crescimento demográfico sob o impulso da criação de renda e de empregos ligados à produção agrícola e às atividades a ela relacionadas. Em 2001, sua população estava ao redor de 19 mil habitantes e a estimativa para 2015 apontava para algo em torno de 80 mil habitantes, segundo dados do IBGE. Com relação à área plantada com lavoura temporária, os dados apresentados na Tabela 1 e os dados sobre a evolução da soja na mesma região e períodos apresentados na Tabela 2 ilustram o crescimento da agricultura. É relevante ressaltar que esse processo é regular ao longo do tempo e não parece apontar para sua estabilização no curto prazo.

Tabela 1 - Área média plantada com lavoura temporária (em ha)

\begin{tabular}{lcccc}
\hline Mesoregião & $1990-94$ & $2000-04$ & $2010-14$ & $\begin{array}{c}\text { Aumento } \\
(\%)\end{array}$ \\
\hline $\begin{array}{l}\text { Extremo Oeste } \\
\text { da Bahia }\end{array}$ & 525.999 & 1.143 .336 & 1.823 .353 & 347 \\
\hline
\end{tabular}

Fonte: IBGE - Produção Agrícola Municipal.

Tabela 2 - Produtividade média da soja (Toneladas/ha) Mesorregião Extremo Oeste da Bahia

\begin{tabular}{lrrrr}
\hline Ano & $1990-94$ & $2000-04$ & $2010-14$ & $\begin{array}{c}\text { Aumento } \\
\text { (\%) }\end{array}$ \\
\hline Área colhida (ha) & 363.132 & 805.640 & 1.159 .248 & 319 \\
\hline Produção (ton) & 691.912 & 1.837 .010 & 3.167 .201 & 458 \\
\hline Produtividade (ton/ha) & 1,91 & 2,28 & 2,73 & 43
\end{tabular}

Fonte: IBCE - Produc̃ão Agrícolo Municipal.

Ainda que a precisão desses dados possa ser questionada, nota-se que houve uma grande ampliação da área plantada com lavoura temporária, o que, em grande medida, se constitui em commodities. Do ponto de vista da produtividade, na Tabela 2 apresenta-se a evolução para a soja e pode-se perceber que o aumento foi progressivo ao longo dos

Tabela 3 - Evolução da área plantada com culturas temporárias em três Microrregiões do MAPITO (ha)

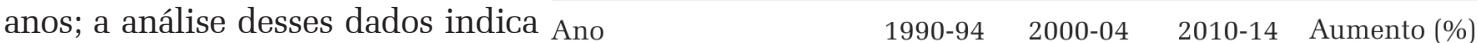

que a expansão da área colhida ocu- Alto Médio Gurguéia - PI $\quad$\begin{tabular}{llll}
\hline Ag.619 & 57.357 & 202.205 & 1.030
\end{tabular}

pa um papel preponderante no au- \begin{tabular}{llllll}
\hline Gerais de Balsas - MA & 60.589 & 208.741 & 439.451 & 725
\end{tabular}

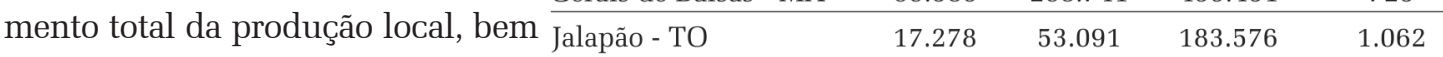

mais do que a progressão da produ-

tividade. Os dados da Tabela 2 não apontam para ras, já que a área colhida aumenta regularmente,

A região também está na origem de grande parte dos investimentos para novas áreas de fronteiras agrícolas vizinhas, particularmente as do Maranhão, Piauí e de Tocantins - conformando uma região chamada de "MAPITO". Ela tem sido considerada como o mais novo "eldorado" para os grandes empreendimentos agropecuários. Esse discurso alia a identificação das potencialidades dessa região à ideia, que já foi utilizada para outras fronteiras agrícolas na Amazônia ou no Oeste da Bahia, de que se trata de um "fim mundo" vazio e desabitado, "um paraíso para s agricultores". Como foi assinalado por um gar estratégico para quem atua no mercado de commodities agrícolas.” Um pequeno extrato de uma matéria publicada em uma revista de grande circulação expõe com clareza o tipo de

O acesso é difícil, as estradas são um verdadeiro caos e em alguns lugares não há, sequer, energia elétrica. Mas ainda assim esse fim de mundo se tornou sinôdorado. Essa é a região do "Mapito", onde Maranhão, Tocantins e Piauí convergem num imenso planalto de terras agricultáveis e de chuvas regulares - um paDa mesma forma que o Oeste da Bahia, a região do "MAPITO” tem experimentado, ao longo dos últimos 20 anos, focos de transformações intensas diretamente vinculadas à expansão do setor agrícola. Três microrregiões, situadas nas áreas fronteiriças entre esses estados, traduzem o rápido crescimento das lavouras a partir do decênio 1990, conforme mostra a Tabela 3 . 
O avanço das lavouras nessas áreas se dá, predominantemente, a partir da "grande agricultura”, cujos agentes têm grande peso na esfera socioeconômica e exercem hegemonia em relação ao uso do solo e ao ordenamento territorial, sendo considerados como os principais produtores do espaço.

Essa agricultura está, mais do que em outras épocas, fortemente vinculada aos circuitos internacionais do mercado das commodities e das empresas transnacionais que atuam a jusante ou a montante da produção de matéria prima agrícola. Pode-se entender, nesse contexto, a inserção do cerrado brasileiro ao sistema agroalimentar mundial como um processo de incorporação de recursos naturais periféricos às cadeias de valor globais, que precisam constantemente se renovar e estender suas fontes de matérias primas para se sustentar no longo prazo, explorando, portanto, espaços cada vez mais afastados dos grandes centros econômicos (Hayter; Patchell, 2015). Inseridas em ambientes extremamente competitivos devido à liberalização e à progressiva globalização dos mercados agrícolas (McMichael, 2009), essas cadeias e seus agentes procuram reforçar as bases de suas vantagens concorrenciais, dentre as quais Porter (1993) ${ }^{4}$ destaca, além dos recursos humanos, os recurc) sos naturais, tais como terra e clima. Enquanto a a criatividade e a economia do conhecimento

${ }^{4}$ Porter considera a concorrência como um processo dinâmico que envolve cinco fatores hierarquizados: recursos humanos, recursos físicos, saberes, recursos em capital e infraestruturas. entanto, oferecem esses recursos naturais em abundância $^{5}$ a preços até então competitivos.

\section{AS MUDANÇAS NO CAMPO E NA AGRICULTURA}

\section{Características e perfis}

Apesar de pertencer, na sua maioria, à "grande agricultura", os produtores se caracterizam por uma ampla diversidade interna em termos de perfis sociais e econômicos. No Oeste baiano, como em outras regióes do cerrado existem, por exemplo, estabelecimentos agrícolas pertencentes a famílias de colonos gaúchos provenientes do sul, que migraram à partir dos anos 1970 à procura de terra ${ }^{6} \mathrm{e}$ que, atualmente, chegam a acumular vários milhares de hectares, lidando com verdadeiras empresas de produção de grãos. Para estes produtores, o processo de migração correspondeu a uma estratégia para se reproduzir como agricultor (Silvestro et al., 2003). Assim, apesar de grandes, os estabelecimentos que têm base familiar partilham a característica de ser, em sua maior parte, empreendimentos realizados por gaúchos ${ }^{7}$ (Alves, 2006; Gaspar, 2010; Haesbaert, 1997). Estes são, com frequência, apresentados como detentores de certo ethos desbravador e colonizador em comparação com outros migrantes, já que se considera o movimento de migrar uma ação socialmente valorizada (Bühler, 2006). Eles se distinguem pelas características de formarem "comunida-

${ }^{5}$ Dentre as vantagens que fizeram despertar o interesse pela região do Oeste da Bahia (e entorno), são destacadas: baixo valor da terra, regime pluvial favorável às principais culturas agrícolas, relevo que otimiza o uso de maquinário em grandes extensões e, segundo o senso comum, a ocorrência de uma vegetação natural de baixo valor, justificando, mais facilmente, o avanço da fronteira agrícola.

${ }^{6}$ Para uma boa análise e caracterização da chegada e estabelecimento dos "Gaúchos" nessa região ver Haesbaert (1997).

${ }^{7}$ Deve ser acentuado que, na região pesquisada, aqueles migrantes que são classificados como "Gaúchos" não são necessariamente provenientes do Rio Grande do Sul; podem ser provenientes também dos outros dois estados da região Sul, do estado de São Paulo ou, ainda, do Centro Oeste com origem sulista. 
des" e manterem seus hábitos culturais e uma estruturação social e produtiva fundamentalmente familiar. Esse perfil convive com o de outros agentes da agricultura, marcados por uma lógica empreendedora e que não se reconhecem como agricultores.

Trata-se, por exemplo, de propriedades pertencentes a investidores originários do Sudeste, do Sul do país ou da capital, raramente domiciliados na região na qual possuem sua propriedade, que atuam com a ajuda de assalariados e gestores especializados baseados no local. Encontram-se também grandes grupos, financiados por investidores nacionais ou estrangeiros, alguns deles agindo através de fundos de investimento. É importante alertar que não é recente o fato de grandes empresas e investidores se interessarem em aplicar seu capital na aquisição de terras no Brasil. Esse processo vem se acentuando ao menos desde a Lei de Terras de 1850, que determinou uma nova relação com a terra mediada pela renda fundiária (Martins, 2009). A busca pela maximização da renda fundiária atraiu muitos investidores para regiões de fronteira agrícola, motivando a ocorrência de conflitos socioambientais, especialmente na Região Amazônica (Esterci, 1987; Martins, 2009). Os maiores interesses se concentram, sobretudo, na especulação fundiária e na perspectiva de diversificar a fonte de renda (industrial, comercial, agrícola). No entanto, o que está sendo percebido atualmente é que essa recente leva de investidores é mais diversa, e sua chegada se faz a partir de novas formas de inserção local, novas relações sociais e novos investimentos produtivos.

Além da diversificação dos agentes que assumem os estabelecimentos agropecuários, existe uma pluralidade de processos que vêm, aos poucos, interferindo nas formas de se produzir no campo. Ao menos três aspectos marcam as mudanças atuais: 1) a emergência de novos agentes, o que faz ampliar significativamente o número e o grau de interações entre eles e agentes já estabelecidos; 2) o aumento médio das áreas dos grandes estabelecimen- tos agrícolas; 3) e a introdução de lógicas relacionadas a um processo de financeirização da agricultura. O surgimento de novos segmentos produtivos, tal como a agroenergia, os avanços tecnológicos (biotecnologia, rastreamento, etc.), ou ainda a intensificação de coordenações na cadeia agrícola, como a integração da produção à indústria que, devido às significativas influências que exercem sobre os mercados, sobre os modos de fazer e, necessariamente, sobre as redes socioprofissionais dos produtores, vêm induzindo a novas práticas e apresentando novas opções de investimento e atuação na agricultura. Essas redes, que passam a incluir agentes que não estão diretamente envolvidos com a produção agrícola, mas que estão fortemente inseridos nos setores agroindustrial, mercantil ou financeiro, servem de elos na transmissão de tendências entre o global e o local. Levá-los em conta como vetores dessas mudanças permite entender, de maneira empírica e prática, as interações entre o surgimento de "novos agentes" na agricultura (às vezes oriundos de agentes tradicionalmente vinculados ao setor), a globalização e o processo de tecnificação do sistema agroalimentar.

Nesse sentido, há, por trás da "grande agricultura”, um universo social diversificado. Em publicação anterior, salientamos e caracterizamos essa diversidade a partir da elaboração de uma tipologia de empresas de produção agrícola no Oeste baiano (Bühler; Oliveira, 2013). Ela foi posteriormente retrabalhada para ser adequada ao âmbito dos principais espaços de expansão do agronegócio na Argentina, no Uruguai e no Brasil (Guibert; Buhler; Requier-Desjardins, 2015). Ainda que possam ser apontadas variações internas a cada perfil, identificamos a ocorrência de três grandes perfis empresariais atuantes na agricultura do MATOPIBA: o primeiro remete a uma empresa de caráter familiar capitalizada, que está integrada verticalmente às cadeias de valor longas e governadas pelos agentes a jusante da produção. O capital é da família e se caracteriza por estar imobilizado; a mão de 
obra é predominantemente familiar e cada vez mais capacitada, o que não elimina a contratação regular de trabalhadores ou a terceirização de parte das tarefas. Tais empresas perseguem uma estratégia empresarial (desenvolvimento do estabelecimento, capitalização, aumento do lucro), mas estão fortemente constrangidas pelo papel atribuído ao patrimônio, que segue sendo gerenciado objetivando sua reprodução ampliada e sua manutenção na família. Costumam ter apenas um estabelecimento e são espacialmente ancorados no local, com forte inserção nas redes políticas e socioeconômicas de proximidade.

O segundo perfil denominamos de empresa patrimonial. São produtores que intensificam seus métodos de produção e consideram que o tamanho se torna um fator distintivo do ponto de vista organizacional. Da mesma forma que os do perfil anterior, estão inseridos nas cadeias de valor, mas dispõem de uma maior margem de decisão em relação à comercialização do produto: são mais capitalizados, conseguem segurar parte da produção para vendê-la conforme a evolução dos preços, ou podem ainda optar por montar uma unidade de beneficiamento (algodão, por exemplo) e agregar valor na propriedade antes de vender. Essa empresa trabalha com capitais próprios, : imobilizados em sua maior parte, mas costu$\therefore$ ma incorporar capitais externos (investidores familiares não agrícolas, ou da rede socioprofissional, ou ainda desconhecidos nacionais ou estrangeiros). Diferentemente do que ocorre no perfil anterior, a divisão vertical do trabalho é forte, recorrendo-se, inclusive, a mão de obra $\stackrel{2}{\wedge}$ altamente qualificada para assumir as funções $\therefore$ de controle e comando. A empresa pode ser or今 ganizada em vários estabelecimentos, distan-

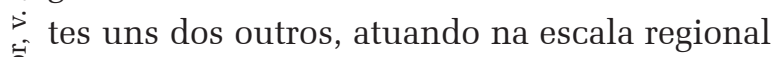
e, às vezes, nacional. Ainda que sua produção esteja espacialmente ancorada, sua escala está circunscrita ao plano regional. Parte da estratégia está voltada para o aumento e manutenção do patrimônio no círculo familiar, sendo que a lógica empresarial se torna mais relevante, aumentando sua importância conforme o peso dos capitais externos na empresa.

Por fim, um terceiro perfil é o da sociedade de investimento. Ela está inserida em cadeias mais curtas, pois seu grande porte lhe possibilita eliminar parte dos intermediários tradicionais, tratando diretamente com escritórios ou fornecedores localizados nos grandes centros globais. As tomadas de créditos se fazem diretamente nas sedes bancárias em São Paulo, da mesma forma que a compra dos insumos se realiza sem passar pelos revendedores locais. Constituídas por capitais externos à atividade agrícola tradicional, tais empresas têm um equilíbrio maior entre custos fixos e variáveis, recorrendo, com frequência, à terceirização de tarefas ou ao arrendamento de terras. Seu tamanho lhes permite adquirir um maior poder de negociação dentro da cadeia de valor, enquanto a alta qualificação dos assalariados que assumem funções de comando e controle contribui para melhorar o domínio que elas têm dos processos e procedimentos internos. Muitas dessas empresas também investem na construção de unidades de processamento de sua produção, visando, com isso, à agregação de valor (menos frequente entre os produtores de soja, e mais frequente entre os produtores de algodão ou milho). Essas sociedades de investimentos costumam articular vários espaços de produção com localizações diferentes. Essa estratégia possibilita reduzir os riscos naturais, especialmente os climáticos e fitossanitários. Sua inscrição espacial vai do regional ao internacional, pois podem distribuir seus escritórios ou registros jurídicos entre vários países. As estratégias seguem um modelo industrial fortemente influenciado pela lógica financeira de especulação e de planejamento do lucro.

O processo de forte atração de investimentos externos à atividade pode ser datado de meados dos anos 2000 e vem alterando as relações dos agentes da produção com o território, produzindo novas dinâmicas sociais, tanto no plano local quanto no global. Na perspectiva de que tais mudanças são produzidas pelos próprios agentes 
e, ao mesmo tempo, são eles mesmos surpreendidos e afetados por elas, observa-se que estes incorporam novas práticas e novas formas de se representar socialmente. $\mathrm{O}$ discurso frequentemente veiculado pelas mídias especializadas e pelos agentes locais busca novas designações para evitar a identificação com categorias já existentes, recusando, assim, a associação à imagem socialmente sedimentada do “agricultor”. Produtor rural ou produtor agrícola são categorias mais usuais, utilizadas, inclusive, por entidades de representação (como o sindicato, por exemplo). Outros exemplos desse exercício semântico podem ser notados pela adoção do neologismo "agroempresário", que designaria a vertente produtiva, moderna e profissionalizada do chamado "agronegócio", identificando o lugar e a figura do "agricultor" inserido nessa ampla designação (agronegócio), que costuma incluir desde agentes da indústria de fertilizantes ou da biotecnologia, até a agroindústria de transformação alimentar. As ponderações feitas por um técnico da Associação de Agricultores e Irrigantes da Bahia (AIBA) expõe os contornos da representação social dos atuais produtores:

[...] agricultura é um negócio complexo, sofisticado, globalizado, sofre interferência do mercado financeiro e por isso apenas pela profissionalização se mantém. É devido a estas características que os pequenos estão sumindo [...]. Antigamente poucos sabiam o que ocorria na economia (bolsa, câmbio) hoje quase todos já se preocupam [...]. Atualmente, deve-se tratar a agricultura como empresa e o agricultor como empresário (Sabai, 2015).

Como é sugerido pelos próprios agentes, a dinâmica socioeconômica e espacial da agricultura de grande porte, influenciada pelo processo de globalização, induz a pensar que grande parte do setor agrícola experimenta uma conformação cujos contornos depende, cada vez menos, do grupo socioprofissional ${ }^{8}$ que a configurou historicamente: os agricultores. Essa agricultura, praticada por produtores

${ }^{8}$ Sobre a categoria socioprofissional "agricultor", ver Hervieu (1996). que se consideram empresários, envolve não apenas os atuais investidores atuantes no nível da produção, mas também agentes presentes ha muito tempo no setor, que cresceram em escala e reestruturaram seu modelo de negócio. A predominância das funções de gestão, comunicação e comando sobre as outras atividades pertinentes a um estabelecimento agropecuário levou certas análises a se referirem a uma agricultura "sem agricultores". ${ }^{9}$

Essas características estiveram bastante visíveis durante a pesquisa empírica, como fica demonstrado pelo extrato de entrevista realizada em 2012 com o gerente que administrava uma fazenda de $49 \mathrm{mil} \mathrm{ha}^{10}$ e que estava em vias de introduzir novas práticas de gestão:

A fazenda é toda on-line, tem um escritório em Barreiras ao qual todas as unidades estarão conectadas, o que permitirá acessar todo o gasto, compra, comercial. Utilizamos um software [...], um modelo de gestão que faz toda a administração da fazenda. É todo um novo pensamento em termos de controle: fiscal, venda, compra [...]. Com a ampliação da fazenda é preciso encontrar o melhor modelo de atuação o mais rápido. Os objetivos são rever rentabilidade que, apesar de não haver prejuízo, pode ser elevada, e preparar a estrutura para poder crescer. Trabalhar com commodities implica se movimentar conforme o mercado.

Assim, vemos que a agricultura de larga escala é diversificada e ainda é possível encontrar formas familiares bastante tradicionais de organização da produção, constituídas por um grupo social para quem a terra se constitui em patrimônio sobre o qual a família se reproduz ao longo de gerações. Por outro lado, verificase que a percepção da terra como atributo da identidade ou patrimônio esta sendo socialmente redefinida, a partir das outras funções que podem ser atribuídas a ela. A primazia crescente, nas grandes empresas e em particular nas empresas de investimento, do obje-

${ }^{9}$ Ver, a partir de diferentes perspectivas Gonçalves (2004), Soto (2008), Hervieu e Purseigle (2011) e Navarro, (2016).

${ }^{10}$ De propriedade de uma família que, na década de 1970 , migrou para a região e adquiriu uma área de 4 mil há, localizada no município de Barreiras, a partir da qual foram adquirindo novas propriedades ao redor. 
tivo de lucro sobre outros objetivos possíveis influencia diretamente a forma de gerir o fundiário e os diversos estabelecimentos agrícolas regionais. Influencia também nas temporalidades, sempre mais curtas, nas quais se inscrevem tais empresas.

\section{As particularidades da agricultura e as mu- danças conceituais}

No debate acadêmico em relação aos rumos do desenvolvimento capitalista na agricultura, algumas análises colocaram em relevo o quanto esse setor da economia continha dimensões hostis ao capital. Vários estudos deram conta de que existiam muitos "Obstáculos ao desenvolvimento da agricultura capitalista" (Mann; Dickinson, 1987). Essa expressão, entre aspas, é justamente o título de um breve artigo no qual esses autores marxistas apresentam uma relevante análise em torno das particularidades que fazem da agricultura um setor diferente dos demais setores da economia e, por isso, menos atrativo ao grande capital. ${ }^{11}$ É a partir dessa explicação que será justificada a permanência e a consolidação de um formato de agricultura cuja gestão do patrimônio, da produção agrícola e da mão de obra estará baIf seada, fundamentalmente, na família ${ }^{12}$ (Wan-

¿ ${ }^{12}$ Que deve ser pensada a partir de vários aspectos: aqueคં les relacionados diretamente à família, à reprodução social

$\checkmark$ e aqueles que se assentam nas dinâmicas comunitárias. Do

$>$ ponto de vista econômico, a dinâmica baseada na família

ठิ se apoia em outra racionalidade, especialmente ao se con-

T siderar que esse tipo de agricultor é detentor do capital e

$\triangleq$ da mão de obra, dotando todo esse sistema produtivo e ๙ social de certa flexibilidade.

I ${ }^{13} \mathrm{O}$ acordo geral sobre o comercio e as tarifas (GATT), que prefigura a OMC e que organizou a liberalização do comércio no planeta depois da Segunda Guerra Mundial, adotava um regime de exceção para os produtos agrícolas. Seu papel estratégico e suas condições peculiares de produção justificavam esse regime. tros autores marxistas,,$^{14}$ que previram o desaparecimento desse tipo de agricultor à medida que o capitalismo fosse penetrando no campo. Os aspectos centrais que compõem tais particularidades se concentram basicamente ao redor das questões ambientais e das características intrínsecas à própria dinâmica da agricultura. Muitos dos aspectos edafoclimáticos, do caráter perecível de parte significativa de seus produtos ou o alto investimento em sua armazenagem, além da dinâmica sazonal da produção e do consequente emprego de mão de obra, fazem da agricultura um setor de difícil industrialização e, portanto, pouco atrativo aos investidores capitalistas. ${ }^{15}$

Esses obstáculos são percebidos pelos agentes e utilizados para se estabelecer uma distinção entre aqueles recém-chegados à agricultura e os que têm tradição nesse meio. Após citar algumas das maiores empresas que se instalaram na região (MSU, Brasilagro, Adeco, Cobra, Vanguarda, SLC), remetendo ao perfil que designamos como "Sociedade de Investimento", o mesmo gerente referido acima faz a seguinte ressalva:

Estes tem um funcionamento bem diferente, são mais apostadores, coisa de curto prazo, arrendam mais, não têm plano de carreira. É um negócio bem capitalista [...]. Estão presentes há pouco tempo, mas não têm grande performance. Essa forma de administrar faz com que sejam pouco eficientes. A agricultura familiar tem uma visão de investimento mais a longo prazo. Anteriormente, teve impacto sobre o mercado de terras, mas hoje não mais. Mas agora estão vendo que a agricultura não é tão simples de se obter lucro. Na agricultura, se lida com clima, com questões culturais diferentes, com pen-

${ }^{14} \mathrm{O}$ próprio Marx demonstrou evidente hesitação em fazer dessa constatação empírica relativa à Europa Ocidental, uma profecia a ser concretizada em qualquer contexto, como passo inevitável para o desenvolvimento do capitalismo e para a passagem a uma nova fase definida pelo socialismo. Sobre isso, ver os "Rascunhos da carta à Vera Zassulitch de 1881". Ver também as análises de Abramovay (1992); (Marx, 2005).

${ }^{15}$ Em várias entrevistas, os produtores agrícolas salientaram que, naquela região a informação mais importante na aquisição de uma propriedade era a sua localização em relação às isoietas que indicavam o maior índice pluviométrico. E a frase mais recorrente que justificava tal preocupação era: "aqui nós não compramos terra, compramos chuva!". 
samentos que se chocam... É preciso maior tempo. É diferente da fábrica onde se faz algo mecânico, na agricultura não é assim, é bem diferente [...].

Outras questões que definiam a agricultura como um setor de significativo risco e hostil à obtenção de taxas de lucros similares a outros setores da economia podem ser apontadas resumidamente a partir de Ramos (2007, p. 23-24):

. Dupla baixa elasticidade da demanda: significa que não há um aumento significativo no consumo de certo produto quando ele diminui seu preço e nem quando se aumenta a renda dos consumidores. O aumento da demanda, para ser expressivo, se daria apenas com o aumento demográfico.

Sazonalidade produtiva e demanda contínua: tal característica impõe custos de estocagem e grande variação no preço dos produtos ao longo de certo período.

. Os diferentes ciclos de produção (perene e anual): eles impõem, em certos casos, a imobilização de um grande capital em investimento, que fica exposto aos riscos naturais.

. Dispersão geográfica: dificulta as potencialidades de uma economia territorial.

. Os limites à economia de escala: há estudos que demonstram que não ocorre incremento nos lucros (om a diminuição de custos) proporcionalmente ao aumento da área. ${ }^{16}$

Mas todas essas características ${ }^{17}$ não impediram que houvesse uma forte industrialização dos insumos e maquinários necessários à produção agrícola e nem um processo intenso de industrialização dessa produção, intermediados por várias cadeias de comercialização (Moraes; Arabe; Silva, 2006; Wanderley, 2009). ${ }^{18}$ Portanto, apesar dessas

${ }^{16}$ Sobre esse aspecto em específico, ver as análises e o conjunto de dados sistematizados por Veiga (1995).

${ }^{17}$ Deve ser acrescentado que o rural e a agricultura também acumularam sobre si uma forte carga de preconceito, que fez edificar uma imagem associada ao atraso e à ignorância, fazendo-os mais distantes como possibilidades socioculturais e econômico-profissionais.

${ }^{18}$ Passou-se por um processo definido por Complexo Rural, em que grande parte das necessidades do sistema de produção agrícola era predominante atendida de forma artesanal e internamente às grandes fazendas que, majo- características que afugentaram muitos capitalistas voltados para maximização da sua taxa de lucro, preferindo investir nos setores a montante e a jusante da agricultura ${ }^{19}$ e deixando essa atividade sob a responsabilidade predominante de grupos familiares, a atração de investimentos nos anos 2000 impõe novas lógicas de gerenciamento e questiona a especificidade da produção agropecuária frente a outros setores.

\section{TÉCNICA, CONTROLE DOS RECUR- SOS E AUTONOMIA DE GESTÃO: O discurso contraditório do desenvol- vimento}

\section{A natureza como recurso produtivo}

O que vem sendo desenvolvido nos cerrados do Brasil somente foi possível na medida em que o avanço da técnica superou os limitantes impostos pelo meio ambiente, especialmente aqueles relacionados às características químicas dos solos. A partir daí, os demais elementos naturais foram convertidos pelos produtores e investidores em ativos (Colletis; Pecqueur, 2005 $)^{20}$ e são apontados, até hoje, como a principal base material da valorização produtiva da região. Isso fica bem expresso na

ritariamente, voltavam-se para os monocultivos. A passagem para o que passou a ser denominado Complexo Agroindustrial (CAI) configurou um forte processo de urbanização e integração vertical da agricultura à indústria, promovendo o que Rodrigues (2009, p.48) chamou de uma divisão social entre o rural e a cidade.

${ }^{19}$ As teses do "apropriacionismo" e do "substitucionismo" na agricultura, defendidas por Gooldman, Sorj e Wilkinson, (1990), apontavam, respectivamente, para a possibilidade de a indústria capitalista se apropriar de elementos necessários ao processo de produção agrícola ou mesmo a própria substituição de determinados produtos, inclusive para a alimentação, por produtos gerados de modo fabril. As condições objetivas que esses autores sugerem para sustentar tais teorias aparecem definitivamente com as modernas biotecnologias.

${ }^{20}$ Colletis e Pecqueur apontam que os elementos do ambiente presentes em um determinado espaço podem ser considerados como recursos quando se constituem em potencial latente a propósito dos quais existe uma possibilidade de valorização nos processos econômicos. Na medida em que esse uso é efetivado e que os recursos são, de fato, mobilizados pelo processo produtivo, eles se tornam ativos e suas características são objetivadas. 
frase extraída de documento prospectivo do Ministério da Agricultura:

As áreas que vêm sendo ocupadas nesses estados têm algumas características essenciais para a agricultura moderna. São planas e extensas, solos potencialmente produtivos, disponibilidade de água, e clima propício com dias longos e com elevada intensidade de sol. A limitação maior, no entanto são as precárias condições de logística, especialmente transporte terrestre, portuário, comunicação e, em algumas áreas ausência de serviços financeiros. (Brasil, 2015)

As inovações no preparo do solo e na engenharia genética (variedades adaptadas ao clima do cerrado) permitiram incorporar o pacote técnico herdado da Revolução Verde a um ambiente até então considerado hostil para a atividade. Dessa forma, o cerrado apenas foi incorporado à dinâmica do agronegócio na medida em que os processos produtivos existentes não precisavam passar por modificações substanciais para serem reproduzidos nesse novo ambiente. Essa adequação entre o modelo técnico-econômico e o meio físico tornou esse último acolhedor e atraente para as finalidades de uma produção capitalista.
Como pode ser notado, a concepção de natureza orientadora da leitura daquela realidade é determinada pela dimensão econômica. Conforme salienta Winner (2002, p.194), "nós deixamos o estado de natureza para garantir o livre acesso à natureza como imenso reservatório de matérias primas úteis. A partir desse gesto, a natureza é designada, uma vez por todas, como uma reserva de bens econômicos." 22

Evidência empírica maior desse tipo de perspectiva pode ser apreendida quando se analisa o mercado de terras. Ao se observar uma ampla zona geográfica que delimita os solos agriculturáveis na região pesquisada, percebe-se que esse mercado está fortemente determinado pelo índice pluviométrico que impõe enorme variação no seu preço. De acordo com dados sistematizados por Sabai (2015), técnico da AIBA, o preço da terra pode variar de 1.300 reais/ha para áreas com índices pluviométricos baixos, a 39.000 reais/ha para áreas com os índices mais elevados. Isso fica visualmente claro quando se considera o mapa das isoietas dessas regiões. Assim, aquelas áreas que ainda não foram desmatadas, mas estão localizadas

Breve apontamento sobre os transgênicos: quando a técnica evidencia interesses de classe

A técnica tem sido fundamental para superar os entraves inerentes à dinâmica da natureza e, nesse sentido, a introdução das sementes transgênicas foi apresentada como o prenúncio de que a indústria de insumos ofereceria aos produtores os meios para se libertarem dos riscos e dos custos impostos pela natureza. No entanto, os depoimentos de técnicos de campo e de produtores agrícolas atestam que estes objetivos estão longe de ser alcançados. Na entrevista que um importante quadro da AIBA nos concedeu, ele destacou que as variedades transgênicas de soja, de milho e de algodão estavam perdendo, cada vez mais rápido, as características que as distinguiam das sementes convencionais, impondo ao produtor custos de produção mais elevados a cada safra. Cita o exemplo da variedade de soja "Intacta", lançada recentemente pela Monsanto e dotada de resistência ao glifosato e a determinadas lagartas, que perde sua resistência em apenas três anos. A promessa de que com as sementes transgênicas se aproximariam da lógica de padronização e industrialização que marcam outros setores da economia não vem, portanto, se confirmando. A noção de pacote tecnológico, muito usual entre agrônomos e produtores, a partir do qual se possibilitava um planejamento do processo produtivo que tomava por referência um roteiro prévio de preparo de solo e aplicação de insumos ao longo de uma safra tem sido colocada em questão.

Mas, além de continuarem expostos a diversos riscos naturais, muitos destes grandes produtores estão atualmente se reconhecendo reféns das empresas de biotecnologia. Ou seja, passaram de uma situação de "parceiros" para uma relação de oposição, sem, no entanto, se constituírem discursos que coloquem em questão o modelo de desenvolvimento em vigor na agricultura. Percebem que há um processo de acumulação capitalista que beneficia de forma muito mais acentuada as indústrias que, além da venda de agroquímicos e das sementes, passaram a cobrar, compulsoriamente, os royalties devidos ao uso de tal inovação tecnológica. Como é salientado por Peschard (2012), as disputas ao redor dos transgênicos, até então polarizadas entre os contrários e os defensores, veem a emergência de novas posições em que a controvérsia maior se refere ao pagamento de enormes somas diretamente às empresas detentoras de tal tecnologia. ${ }^{21}$ Tal situação tem feito com que alguns grandes agricultores, até então céticos quanto ao uso de técnicas de controle biológico de pragas passassem, como foi mencionado em entrevista, a incorporar tais práticas, adotando parte dos próprios elementos da natureza como aliados para enfrentar as multinacionais das sementes.

${ }^{21}$ Para compreender como se dá o processo de cobrança e pagamento de royalties, bem como as controvérsias contratuais e jurídicas na relação entre agricultores e a Monsanto. Reis (2009)

22 "Nous avons quitté l'état de nature pour garantir um libre accès à la nature comme un immense réservoir de matières première utiles. Dans ce geste, la nature est désignée, une fois pour toutes, comme une reserve de biens économiques." 
em perímetros de maior incidência de precipitação são as mais cobiçadas pelos investidores. Daí as motivações que estiveram na base das intensas disputas em torno da revisão do Código Florestal ficam explícitas, particularmente no que se refere à resolução que permite ao produtor localizar sua reserva legal distante de sua propriedade, desde que tal reserva seja pertencente ao mesmo bioma no qual está localizada a propriedade.

Deve ser notado que o discurso que predomina entre os produtores, agentes públicos e privados atuantes no "desenvolvimento" dessas regiões sempre inclui o potencial de abertura dessas novas áreas, pressionando, cada vez mais, a fronteira agrícola. Assim, segundo o documento mencionado, alguns municípios do Oeste da Bahia possuem os seguintes potenciais de abertura de novas áreas: Luis Eduardo Magalhães ainda tem um potencial de ampliação de área agrícola em aproximadamente 40\%; São Desidério e Formosa do Rio Preto ao redor de $60 \%$, Cocos tem um potencial de $94 \%$. Vale insistir que esse potencial está diretamente relacionado à abundância dos "recursos" naturais indicados acima.

Dessa forma, junto com o potencial agronômico, entram em conta as possibilidades futuras de acumulação e valorização fundiária no momento da compra. Além de base material da produção imediata, a natureza representa também uma reserva para usos possíveis e lucros futuros. O esgotamento desse meio não aparenta ser uma preocupação que justifique impor limites à expansão e à reprodução do modelo agrícola aí vigente. Tal postura é fortalecida pela crença de que o desenvolvimento da técnica será capaz de superar os limites ainda não superados para a incorporação de mais áreas ao processo de produção capitalista. É pela técnica que também será possível, na visão de muitos desses agentes, corrigir os efeitos destrutivos desse modelo. A leitura que se faz da natureza, nesse sentido, é essencialmente utilitarista. Ou seja, a natureza não tem um valor intrínseco, pois o seu valor está diretamente relacionado à contribuição que pode oferecer ao crescimento econômico. Essa concepção é bastante compartilhada pelos produtores agrícolas que, nas entrevistas, quando se menciona a abertura de novas terras, não costumam demonstrar preocupação em relação aos impactos da agricultura sobre o funcionamento dos ecossistemas, ou considerações de ordem ética sobre a natureza que eles exploram. Com efeito, o que é recorrente é a crítica ao ambientalismo e a promoção de estratégias para superar as leis e os discursos de proteção do cerrado.

Os agentes que regulam o setor participam da legitimação da abertura de terras através da retórica e da construção de dados que visam, de um lado, a distinguir o cerrado da Amazônia, e de outro a construir um discurso da disponibilidade do cerrado para fins produtivos. Os órgãos públicos, a começar pela Embrapa (Empresa Brasileira de Pesquisa Agropecuária), tiveram um papel decisivo nesses processos de adequação técnica do cerrado à agricultura capitalista (Bühler; Oliveira, 2013) e de consolidação do discurso sobre um bioma a ser explorado (Contini et al., 2010). Os órgãos centrais do Estado têm participação fundamental nesse processo, inclusive a partir de discursos legitimadores do tipo de prática que se efetiva nas atuais fronteiras agrícolas. Exemplo mais bem acabado desses discursos foi protagonizado pelo Ministro da Agricultura Wagner Rossi (2010-2011), que teria dito, em evento público em 2011, que a expansão da agricultura sobre o cerrado nordestino não ia produzir maiores impactos ambientais, pois "lá não tem nada, só cerrado" (Camargo, 2011).

Com as pressões dos lobbies ambientalistas e da sociedade civil, é possível notar, no entanto, que houve certa mudança na forma de tratar o cerrado, passando-se a considerá-lo como um bioma relevante (Aubertin; Pinton, 2013) na medida em que cumpre importantes funções ecossistêmicas. Apesar disso, permanece a visão contraditória de um cerrado com vocação agrícola, como atesta essa apresenta- 
ção de um projeto de mapeamento do uso do solo liderado pela Embrapa:

O estudo é considerado estratégico também pela relevância do bioma cerrado. Trata-se da savana mais rica do mundo em biodiversidade, com uma flora de mais de 12 mil espécies e que nas últimas décadas tornou-se um dos maiores produtores de alimentos do mundo com o suporte de tecnologias adaptadas à região. ${ }^{23}$

Essa visão é reproduzida pelos agricultores e investidores da região; a pouca visibilidade do bioma na agenda ambiental internacional, e a menor atenção dedicada a ele frente à Amazônia, fez com que certos investidores se sentissem mais à vontade para investir seu capital nessa região. Quando questionado sobre os motivos que o levaram a localizar seu investimento no oeste da Bahia, um produtor originário dos Estados Unidos mencionou como principais elementos a logística, o ambiente político estável, o solo e o clima, que permitiam uma flexibilidade na escolha das produções e a possibilidade de expansão. Ao estabelecer uma comparação entre aquela região e as frentes amazônicas, considerou, por um lado, a falta de transparência do mercado fundiário amazônico e, curiosamente, colocou à frente um argumento de fundo moral, o respeito pela Amazônia: "é sagrado, a gente não $\stackrel{\vartheta}{\circ}$ deve mexer". Por outro lado, a natureza pre$\therefore$ sente no Oeste Baiano foi tratada de forma depreciativa: "só tem cobra e passarinho, não tem nem macacos... [cita outras espécies animais]. Os lugares com ecossistemas complexos são situados próximos à água [portanto não ex¿. plorados]" (Fonte: entrevista com investidor e ^ produtor, 2011).

కิ ${ }^{23}$ Essa contradição encontraria sua resolução na afirmação das finalidades de monitoramento associadas ao mapeamento: "As informações geradas irão facilitar o monitoramento do uso das terras, a definição de áreas para a - implantação de sistemas de ILPF (Integração Lavoura Pe-

Tuária Floresta) e o estabelecimento de novos cenários da

ช agricultura no cerrado brasileiro, o que contribuirá, segun-

- do ele [um dos coordenadores do trabalho], para o desen-

volvimento rural sustentável." (https://www.embrapa.br/

busca-de-noticias/-/noticia/7808194/mapeamento-inedito-

mostra-uso-e-cobertura-do-cerrado)

\section{A abundância de recursos naturais como horizonte futuro de reprodução}

Essas fronteiras agrícolas neoliberais, conforme definição de Brannstrom (2009), podem ser consideradas como lugares fortemente submetidos à degradação ambiental e como espaços-tempos chave dos processos de incorporação dos recursos naturais, os quais, por sua vez, são convertidos em ativos no circuito econômico. São espaços de transição, mas também espaços em transição, que são atravessados por diferentes e sucessivas fases de exploração (Bernardes, 2005; Machado, 1994; Martins, 2009). Ou seja, a própria noção de fronteira indica a passagem de um estado a outro e, ao mesmo tempo, a saída de determinado estágio para estágios com outro grau de exigência técnica e produtiva. Nesse processo, agentes se renovam, e a utilização dos recursos se intensifica. A dinâmica desses espaços está igualmente vinculada às transformações das regiões agrícolas mais antigas, que têm tendência a adotar métodos produtivos sempre mais intensivos. As estatísticas agrícolas regionais mostram, por exemplo, que a intensificação, nas regióes próximas dos grandes centros de consumo, impulsiona os sistemas mais extensivos sobre as margens, contribuindo para a ampliação dos limites espaciais das atividades agrícolas. Nessas regiões, são encontradas as tendências compartilhadas nos grandes países agrícolas da América do Sul na sequencia do aquecimento do mercado agrícola dos anos 2000, quando a intensificação dos espaços agrícolas consolidados empurra as fronteiras agrícolas para mais adiante (Guibert, Buhler; Requier-Desjardins, 2015). Nesse caso, o uso mais intensivo dos solos conduz, paradoxalmente, a uma desconcentração agrícola em relação a uma escala mais ampla, acompanhado de uma degradação dos meios naturais na periferia. As empresas agrícolas, no entanto, queimam etapas e se instalam diretamente à montante das fronteiras agrícolas, como mostram as observações nas regiões pesquisadas. 
Segundo Brannstrom (2009), trata-se de uma evidência do processo de neoliberalização da fronteira agrícola, o que remete à pouca intervenção do Estado para conter esse movimento, à descentralização das decisões ambientais para escalões administrativos inferiores por falta de orçamento, ou com finalidade de flexibilizar a regulação ambiental (as disputas em torno da reforma do Código Florestal têm relação com essa configuração), assim como à tendência à especialização produtiva crescente desses "novos" espaços, levada a cabo por agentes corporativos de média e grande escala, diretamente articulados com o mercado global das commodities. O conjunto desses espaços da agricultura neoliberal, novos ou mais consolidados, sustentam as políticas desenvolvimentistas dos Estados, que, por esse motivo, também, têm uma margem de regulação ambiental reduzida. Com inspiração na literatura sobre justiça ambiental, essas áreas, dedicadas ao avanço da fronteira agrícola, constituem o que alguns autores chamam de "zonas de sacrifício” Hecht (2005 apud Brannstrom, 2009), ou seja, zonas criadas como territórios para o desenvolvimento da agricultura neoliberal, em que não há um grande rigor quanto ao controle ao uso dos recursos ambientais. Esses espaços periféricos, altamente especializados e capazes de fornecer grandes volumes de produção ao mercado mundial, podem ser comparados ao que McMichael (2009) chama de "arquipélagos" de plantações no Sul global. ${ }^{24}$ A noção de arquipélago remete a áreas descontínuas, mas articuladas em âmbito global e especializadas na produção voltada para os grandes mercados consumidores concentrados, como é o caso da Europa e China no que se refere à soja.

${ }^{24}$ McMichael se refere, com essa expressão, aos espaços fornecedores de frutas e vegetais não estacionais para os mercados do Norte ou para as classes médias e altas do Sul, mobilizados de forma complementar ao longo do ano por corporações sediadas, na maioria dos casos, num pais do Norte.

\section{Commodificação e controle como meios da apropriação da natureza}

Para mobilizar os recursos situados nas periferias da produção agrícola globalizada, é necessário passar por um processo de commodificação da natureza. Segundo Castree (2003), trata-se de um processo delimitado por alguns aspectos fundamentais: privatização, alienação, individuação, abstração, valoração, deslocamento. Observa-se, nesse sentido, uma dinâmica de apropriação privada dos recursos naturais, processo que, nessas regiões de fronteira agrícola, se dá de forma frequentemente fraudulenta e conflitiva. Aspectos da natureza que aparentemente seriam inalienáveis, como o clima, a chuva, o relevo, são incorporados ao mercado fundiário e, nesse processo, se transformam em mercadoria. Aliás, como foi mencionado anteriormente, os produtores dessa região costumam dizer que ali "não se compra terra, se compra chuva”. A dinâmica de individuação é definida pela capacidade de separar elementos da natureza do seu contexto, tanto como representação quanto do ponto de vista físico. A abstração refere-se à assimilação de um determinado elemento da natureza, inserido numa diversidade de outros elementos, a algo mais amplo, visando à sua equiparação e, assim, poder tomar parte do mercado. A valoração aponta para o fato de que a atribuição de valor a determinado bem segue apenas a lógica do dinheiro, pois outras formas de expressar o valor são convertidas e reduzidas ao seu valor monetário. O deslocamento corresponde, por sua parte, à separação do bem de seu vendedor e do seu comprador.

Esse processo de commodificação da natureza tem efeito direto na dinâmica social, econômica e cultural dessas regiões pesquisadas. A representação social da natureza da região e a atribuição de valor a seus componentes foram se alterando, e os conflitos se intensificando. Antes do interesse econômico pelas extensas áreas de planalto dominadas pelo bioma cerrado, havia uma dinâmica 
complementar entre os vales, mais valorizados economicamente, onde se praticava a agricultura, e o planalto, onde predominava a pecuária extensiva. A concepção acerca da relação entre sociedade e natureza estava apoiada em representações sociais bastante diferentes das que dominam atualmente nesses espaços. Há, evidentemente, um processo marcado por relações de poder, em que agentes dominantes no campo econômico se fortalecem e se aliam a agentes do campo político e produzem discursos poderosos que, objetivamente, criam novas realidades, emergindo a partir de lutas simbólicas e, sobretudo, conflitos abertos pelo domínio dessas regiões. Conforme foi descrito por um técnico especializado na medição de terra e atuante também no mercado imobiliário em Bom Jesus (PI),

Essa é uma região de muitos problemas. Em 1986, não havia nada desmatado. As datas ${ }^{25}$ eram criadas na parte de baixo onde havia água. Por isso, não havia datas no cerrado. O cerrado passou a valer mais que as áreas baixas, e os produtores passaram para a parte de cima, estendendo suas escrituras para as áreas de cerrado.

A situação descrita comprova que o sistema de acumulação capitalista incorpora os diversos regimes do "direito" (Harvey, 2010). O que significa dizer que a pretensa impessoa: lidade e a burocratização do Estado e do mer$\therefore$ cado não evitam que regras sejam gestadas e aplicadas de maneira informal. Esse movimento não é promovido apenas por uma dinâmica

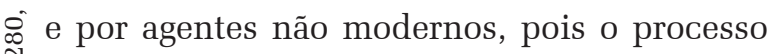
요 de acumulação capitalista enseja e se beneficia $\stackrel{N}{\grave{2}}$ de tais dinâmicas, gerando e fomentando for^̃ mas "subterrâneas" do direito.

a Essa valorização do mercado fundiário ฟิ e a commodificação da natureza são acirrados í pela chegada de grandes grupos econômicos, que deslocam parte dos agricultores aí presentes para outras áreas de menor custo. ${ }^{26}$ As-

${ }^{25}$ Unidade de medida utilizada até 1822 , relacionada ao sistema de sesmaria e equivalente a 13.068 ha.

${ }^{26}$ Deve ser ressalvado que esses diferentes movimentos não constituem exclusividade de um ou de outro perfil. Mesmo em áreas que foram recentemente incorporadas sim, é como se aqueles agricultores que ainda atuam segundo uma lógica familiar, mas dotados de grandes extensões de terra, se vissem pressionados por empresários ou grandes grupos capitalistas fortemente capitalizados a se deslocarem para essas novas áreas, nas quais ainda predomina a vegetação nativa, áreas carentes em infraestrutura e, em grande parte, com documentação irregular. Em certo sentido vão criando as condições para a chegada dos grandes capitalistas reproduzindo, em muitos casos, o mesmo movimento que fizeram quando saíram do sul do país. Ou seja, a partir do que acumularam, conseguem adquirir áreas muito maiores, ainda que em condições precárias, nessas novas fronteiras.

Verifica-se, nessas duas frentes, o que Harvey (2010) denomina de acumulação por espoliação, o que, segundo esse autor, é intrínseco ao capitalismo. Há um processo de inclusão de novas áreas à dinâmica produtiva do capitalismo, o qual usufrui de vantagens comparativas à custa da expropriação e da destruição da natureza. A região pesquisada, particularmente o estado do Piauí, é marcada pelo encontro entre lógicas que caracterizam o estágio mais avançado do capitalismo e as lógicas primitivas de acumulação (Marx, 1996 [1890]). Os mecanismos de produção e legalização de títulos de propriedades constituem um exemplo flagrante deste processo, gerando conflitos entre agentes privados e entre eles e os agentes públicos. Há, assim, muitos casos de contestação das propriedades por outros donos, legítimos ou não, que reivindicam a terra alvo da transação, inclusive em situações mediadas pela justiça. Observamos que essa dinâmica enseja o surgimento de novos agentes especializados em "esquentar" os documentos dessas áreas. Ou seja, escritórios de advocacia ou agentes imobiliários utilizam diversas vias, ou para verificar a legalidade dos documentos, ou para legalizá-los caso persistam pendências. Dependendo dos casos, tais ao processo produtivo, verifica-se a presença de grandes grupos. 
situações são resolvidas de forma conflitiva: existem numerosos casos de sobreposição de títulos de propriedade descobertos na medida em que as terras vão sendo adquiridas. Como observou outro agente imobiliário, há o caso em que o comprador adquiriu três títulos da mesma propriedade (para evitar os conflitos) e, ainda assim, precisou recorrer ao judiciário para regularizar a situação devido ao aparecimento de outro pretenso proprietário.

A forma de superar tais obstáculos ou evitá-los passa pelo estabelecimento de relações com os agentes locais (Bühler; Frederico, 2015). Essa necessidade ficou evidente quando percorremos uma extensa área na Serra do Quilombo em Bom Jesus ${ }^{27}$ na companhia de uma agente imobiliário especializado na venda de fazendas no estado. Ainda que possa haver certos exageros, ficou notório como se trata de um mercado em que o conhecimento técnico é importante, mas, sobretudo, são as relações sociais que constituem o diferencial determinante. Ao longo de todo o percurso (ao redor de $250 \mathrm{~km}$ ), ele identificava nominalmente todos os proprietários, as áreas à venda, aquelas áreas com problemas judiciais, o histórico de conflitos, etc. Citou também as várias formas de resolver casos de conflitos, ou o uso de certas táticas para afastar eventuais agentes que se arrogam algum direito (real ou usurpado) sobre uma propriedade à venda, sendo que o recurso ao judiciário representava sempre uma ação limite. Tratava-se de um agente que, para atuar naquele mercado, tinha mapeado as principais questões históricas de caráter judicial e os principais agentes locais, conhecendo também as formas de pressioná-los em caso de reivindicação sobre uma terra. Apenas com esse tipo de investimento seria possível, segundo ele, oferecer garantias aos compradores de fazendas naquela região.

De todo modo, o que notamos é que esse processo não é conduzido por grandes empresas do agronegócio. Essas empresas chegam

${ }^{27}$ Local em que se concentram as áreas de cerrado ainda por serem abertas e as grandes fazendas. quando os conflitos e as incertezas já foram, em grande medida, solucionados". No geral, aqueles que estão expostos a essa dinâmica chegaram ali provenientes de outras áreas para as quais já haviam se deslocado. Saíram do sul, passaram por Mato Grosso ou pelo Oeste da Bahia, movidos pela mesma lógica de acumular cada vez mais capital. A acumulação de capital, nessas áreas de expansão do agronegócio, está diretamente relacionada com o tamanho da área produtiva. Assim, quando o estoque de terras para ser aberto é muito restrito, quando as áreas se tornam muito caras, o movimento de migração é retomado. Esse movimento pode ser bem sucedido, mas pode acarretar, como nos foi narrado em vários momentos, situações de grande prejuízo e até de total empobrecimento.

O grande investidor capitalista evita esse tipo de risco, pois chega a essas áreas visando às propriedades que já se encontram em estágio produtivo e legalizadas, ou que oferecem um alto potencial de valorização através da abertura de novas áreas para que sejam incorporadas à dinâmica de produção. Em ambos os casos, alguns escândalos emblemáticos fizeram com que os investidores ficassem mais atentos à legalidade dos documentos. Para evitar riscos desse tipo, alguns deles preferem adquirir parte do capital de empresas já estabelecidas, ou constroem joint-ventures. Nesse caso, eles tendem a dividir juridicamente as empresas de produção agrícola, isolando a parte fundiária da parte produtiva, deixando o risco jurídico para o produtor local. Conseguem, dessa forma, o controle da terra, sem assumir os riscos - e os investimentos - da propriedade.

Essa dinâmica coloca o fundiário como elemento indispensável à produção de commodities, mas também como fator de especulação e como parte de um processo de financeirização da agricultura (Fairbairn, 2014; Ouma, 2014). A acumulação, conforme aponta Fairbairn, se dá a partir da produção, mas também a partir da especulação e da financeirização. Nesse sentido, encontramos empresas estrangeiras e nacio- 
nais que possuem investimentos nas regiões do agronegócio cujo retorno do capital investido poderá se dar, principalmente, a partir da especulação imobiliária ou da especulação sobre os títulos financeiros. Portanto, ainda que a ampliação da área possa objetivar maior competitividade produtiva, pode ocorrer, no entanto, que o interesse esteja, prioritariamente, no mercado imobiliário (Borras et al., 2012).

Nesses espaços, a gestão e as iniciativas de conservação da natureza também têm caráter neoliberal, pois há, neles, uma ampla sujeição da natureza à lógica de acumulação capitalista. Entretanto, paradoxalmente, essas regiões de expansão da grande agricultura são espaços privilegiados para discursos recorrentes sobre preocupações com o meio ambiente e com as questões sociais. É nelas que ocorre a implantação de programas de "boas práticas", como o Plano ABC (Agricultura de Baixa Emissão de Carbono), iniciativas de rastreabilidade (Moratória da soja; Soja Plus), selos de qualidade (socioambiental, ISO). O meio ambiente, portanto, é imposto como um objeto de lutas e de posicionamento para o espaço agrícola e para acesso aos mercados. Tal movimento nos parece se aproximar daquilo que, nos termos de Hariet Friedman (2005 apud McMichael, 2009), constituiria uma transição para o regi\& me alimentar "corporativo-ambiental", em que . lideranças corporativas integram a crítica ambiental e a demanda social a ela associada ao seu modelo econômico, visando a superar as restrições impostas pelo mercado e, ao mesmo tempo, alcançar benefícios e incentivos pro$\stackrel{\circ}{\sim}$ venientes do Estado relacionados à noção de $\therefore$ sustentabilidade.

\& $\quad$ Ao tomar o exemplo da AIBA - organiș zação de representação que se mantém com $\therefore$ recursos dos produtores agrícolas -, percebe-se claramente a expressão desse discurso contraditório, que explicita, por um lado, uma pretensa preocupação com a questão ambiental e social, mas, no processo de representar e auxiliar os produtores, atua no sentido de contornar as regras e as leis estabelecidas.
Promove fortes críticas ao Estado, mas investe fortemente no lobby político e nas disputas eleitorais para se fazer presente nos espaços de representação do Estado. Nesse sentido, o que emana do Estado está fortemente determinado por tal influência e tal participação. Conforme estrato de entrevista com um de seus técnicos, esses aspectos ficam evidentes:

[...] a AIBA defende o setor, auxilia os produtores. Entrou com ação contra o Funrural (Fundo de Apoio ao Trabalhador Rural), que é o INSS (Instituto Nacional do Seguro Social) do rural e conseguiu a isenção junto ao governo federal. [...] A AIBA visa a promover o agronegócio considerando o econômico, o ambiental e o social. Auxilia no processo de regularização ambiental das propriedades (Plano de Adequação e Regulamentação Ambiental, PARA, Plano Oeste Sustentado). Faz cotações diárias de preço, faz lobby político, soluciona problemas comuns (Sabai, 2015).

Nota-se que a preocupação com o social está submetida aos interesses econômicos do setor. Atuar para flexibilizar os direitos trabalhistas tem sido uma das mais importantes causas dessas organizações de representação. Um dos fazendeiros que entrevistamos é contundente quando afirma: "Na época em que chegamos, em 1981, estávamos em 3 irmãos. A mão de obra era muito mais fácil do que hoje. Não tinha Ministério do Trabalho. Não sabia da legislação e não tinha fiscalização". Da mesma forma, também há um grande investimento dessas organizações para superar os "entraves" ambientais, especialmente em relação ao pagamento de multas e à permissão para abertura de novas áreas (Brannstrom, 2009).

\section{CONCLUSÃO}

A relação desses agricultores com o espaço está regida por uma lógica fortemente instrumental, segundo a qual o sentido de patrimônio da terra é progressivamente substituído pelas lógicas do capital, e o espaço de produção deixa de ser também um espaço de vida, como ocorre, predominantemente, no 
caso da agricultura familiar (Wanderley, 2009). No processo inicial de sua territorialização, os agricultores, junto com as organizações do setor, investem num discurso para definir a área na qual atuarão como sendo um espaço de "vazio social" e ambiental, antecipando e legitimando sua instalação. A partir desse discurso, busca-se a constituição de um território em que o caráter civilizatório, assentado na ideologia do progresso, passa a informar as relações sociais e com o espaço. Ou seja, no lugar do "vazio" se implanta um processo produtivo dotado de intensa tecnologia, gerido com ferramentas de gestão até então pouco encontradas em tal atividade. É a partir desse patamar que se define o parâmetro para marcar o divisor entre o progresso e o atraso. Esse processo, que inicialmente se dá a partir de uma desconstrução simbólica, consolida-se econômica e socialmente promovendo novas formas de relações de poder, visando à normalização da realidade, nas quais se veem enredados vários outros agentes sociais (Fernández, 2010). Em outros termos, pode-se pensar que a consolidação desses projetos, interesses e práticas dos novos agentes da agricultura na região, acirram-se as relações de poder e os conflitos, assim como se transforma a maneira de pensar e de representar o local e a relação entre sociedade e natureza.

Essas são as bases a partir das quais a região pesquisada se consolida e passa a atrair, nos anos 2000, novos agentes investidores. A natureza, seu domínio, a percepção de sua abundância e sua desvalorização como ecossistema se tornam aspectos-chave da atratividade da região e dos modos de exploração dominantes. Nessa perspectiva, alguns elementos da natureza deixaram de constituir obstáculos e outros passaram a ser indispensáveis para a expansão da agropecuária no cerrado. Como fica notório nos discursos de valorização dessas fronteiras agrícolas, com a integração das técnicas e do trabalho que as tornarão produtivas, esses elementos naturais constituem a base material que vem permitindo a inclusão dessas áreas periféricas ao circuito global de acumulação capitalista. Para tanto, o meio natural precisa atender a alguns critérios preestabelecidos como imprescritíveis para se tornar objeto de cobiça por parte dos produtores e investidores que costumam considerar um conjunto de elementos (clima, relevo, fontes de água, índice pluviométrico, etc.). Tais elementos acabam produzindo um zoneamento com contornos nem sempre claros, que pondera as possibilidades evolutivas (conforme as inovações técnicas) da atratividade do espaço para a agricultura. Acabam formando, paralelamente, a principal lente a partir da qual o setor agropecuário avalia, qualifica e pensa o meio natural.

Em síntese, podemos afirmar que está em curso um processo de neoliberalização do meio ambiente (Higgins et al., 2014) no espaço rural local. Tal processo se caracteriza por um reagenciamento das regulações estatais do meio ambiente que questionam e reorientam os padrões da regulação pública. As tendências marcantes desse processo são as seguintes (Woods, 2011): 1) Ele desafia os regimes estatais estabelecidos de apoio à agropecuária, controlando a abertura comercial para os produtos agrícolas. 2) Promove a commodificação e privatização da natureza ou dos recursos naturais. 3) Aumenta a regulação a partir de mecanismos de mercado que passam a investir em "ações verdes" (Higgins et al., 2014) acrescentam que esses processos submetem os agentes rurais a conjuntos de regras técnicas (tecnology of rules) mais presentes e imponentes, que os submetem à disciplina de mercado e a processos de "auditoria" (declaração do CAR, selos socioambientais, etc.).

Finalmente, fica o questionamento acerca do futuro desses sistemas e da sua regulação. Há uma pressão social interna e externa ao país, apoiada pelos mercados consumidores, para se intensificar o controle sobre a abertura de terras e a conservação dos serviços ecossistêmicos do cerrado. O tratamento dessas questões foi, por enquanto, deixado sob a agenda neoliberal, flexibilizando-se o Código 
Florestal, estabelecendo-se sua implementação de forma descentralizada e privilegiando-se as ações voluntárias (Plano ABC, adesão a selos privados ou a programas de boas condutas) dos agentes do setor. Diante das situações críticas - exacerbadas por um modelo de precária regulação, pelo acirramento das tensões sociais associadas à falta de água e pela consolidação dos movimentos ambientalistas -, poder-se-ia se esperar uma reavaliação pelo poder público dos instrumentos da gestão ambiental em contexto agropecuário. Entretanto, as crises “cíclicas”, de caráter político e econômico, e a importância do setor na economia nacional não apontam para tal movimento. Pode-se considerar que o próprio setor se veja provocado a introduzir novas lógicas de atuação que poderiam relaxar, ao menos temporariamente, a pressão sobre a região uma vez constatado, por exemplo, a ocorrência de rendimentos abaixo dos esperados e de certa "debandada" dos investimentos externos ao setor em consideração às taxas de lucro inferiores as expectativas ou às dificuldades para vender a terra em contexto de queda no preço das commodities. No entanto, as experiências passadas mostram que, em tempos de crise, o setor procura reverter a diminuição de seus lucros pela incorporação de novas terras, mesmo que sem a presença 을 significativa de capitais externos ao setor agrí‥ cola. Não nos parece, nesse sentido, que, em um futuro próximo, as áreas de cerrado contarão com práticas auspiciosas que visem à sua c conservação.

\section{REFERÊNCIAS}

ABRAMOVAY, Ricardo. Paradigmas do capitalismo agrário em questão. São Paulo: Hucitec; Campinas: Ed. Unicamp, 1992.

ALVES, Vicente Eudes Lemos. Mobilização e modernização nos cerrados Piauienses: formação territorial no império do agronegócio. 2006. 320 p. Tese (Doutorado) - Programa de Pós-Graduação em Geografia Humana, Faculdade de Filosofia, Letras e Ciências Humanas da Universidade de São Paulo, São Paulo, 2006.

AUBERTIN, Catherine; PINTON, F. L'invention du biome cerrado. Confins [Online], França, n. 17, 2013. Accessível em: http://confins.revues.org/8218; DOI : 10.4000/confins.8218. Acesso em: 15 maio 2014.

BATISTA, Fabiana; INÁCIO, Alexandre. "Agricultura coorporativa” ganha espaço no país. Jornal Valor, São Paulo, 31 maio 2011.

BERNARDES, Júlia Adão. Circuitos espaciais da produção na fronteira agrícola moderna: BR-163 matogrossense. In: BERNARDES J.A., FREIRE FILHO O. L. (Org.). Geografia da soja - BR-163: fronteiras em mutação. Rio de Janeiro: Arquimedes Edições, 2005. p. 13-37.

BORRAS Jr., Saturnino M. Land grabbing and global capitalist accumulation: key features in Latin América. Canadian Journal of Devlopment Studies/Revue canadienne d'études du développement, Salvador, Ba, v. 33, n. 4, p. 402-416, 2012.

BRANNSTROM, Christian. South Americas's neoliberal agricultural frontiers: places of environnmental sacrifice o conservation opportunity?. Ambio, África, v. 38, n. 3, p.141-149, 2009.

BRASIL. Projeções do agronegócio. Brasil 2014/15 a 2024/25. Projeções de longo prazo. Brasília: MAPA, 2015. Disponível em: http://www.agricultura.gov.br/arq_editor/ PROJECOES_DO_AGRONEGOCIO_2025_WEB.pdf. Acesso em: 28 mar. 2016.

BÜHLER, Ève Anne. Les mobilités des exploitations rizicoles du Rio Grande do Sul (Brésil) vers l'Uruguay. 2006. 489 p. Tese (Doutorado em Etudes Rurales) - Institut National Polytechnique de Toulouse, Toulouse, 2006.

; FREDERICO, S., Capital financeiro e expansão da fronteira agrícola no oeste da Bahia. In: Alves, V.E. L. (Org.) Modernização e regionalização nos cerrados do Centro-Norte do Brasil. São Paulo: Consequência, 2015. p. 199-225.

; OLIVEIRA, V. L. La localisation des entreprises agricoles dans l'ouest de l'état de Bahia au Brésil. Études rurales, Paris, v. 1, n. 191. p. 91-113, 2013.

CAMARGO, Renata. O ministro da agricultura pisou no pequi. In: UNB clipping. Disponível em: http://www.unb. br/noticias/unbagencia/cpmod.php?id=86187. Disponível em: 20 mar. 2016

CASTREE, Noel. Commodifying what nature?. Progress in Human Geography, Caribe, v. 27, n. 3. p. 273-297, 2003.

COLLETIS, Gabriel; PECQUEUR, Bernard. Révélation de ressources spécifiques et coordination située. Économie et institutions, [S.1], n. 6-7, p.51-72. 2005.

CONTINI, Elisio. et al. Dinamismo da agricultura brasileira. Revista de política agrícola. Brasília, p. 42-64, 2010.

ELIAS, Denise. Agronegócio e desigualdades socioespaciais. In: ELIAS, D.; PEQUENO, R. Difusão do agronegócio e novas dinâmicas socioespaciais. Fortaleza: Banco do Nordeste Brasil, 2006. p. 25-82.

ESTERCI, Neide. Conflito no Araguaia: peões e posseiros contra a grande empresa. Petrópolis: Vozes, 1987.

FAIRBAIRN, Madeleine. Like gold in yeld: evolving intersections between farmland and finance. The Journal of Peasant Studies, Inglaterra, v. 41, n. 5, p. 777-795, 2014.

FERNÁNDEZ, Antonio João Castrillon. As "novas" territorialidades no processo de expansão das lavouras de soja. IN: CONGRESSO DA SOBER, 48., 
2010, Campo Grande. Anais eletônicos... Campo Grande: SOBER, 2010. Disponível em http://sober.org. $\mathrm{br} / ? \mathrm{op}=$ paginas $\&$ tipo $=$ pagina $\&$ secao $=7 \&$ pagina $=35$ Acesso em: 05 mar. 2016.

GASPAR, Rafael Bezerra. O eldorado dos gaúchos: deslocamento de agricultores do Sul do país e seu estabelecimento no Leste Maranhense. 2010151 p. Dissertação (Mestrado) - Programa de Pós Graduação em Ciências Sociais da Universidade Federal do Maranhão, 2010.

GONÇALVES, Carlos Walter Porto. Geografia da riqueza, fome e meio ambiente: pequena contribuição crítica ao atual modelo agrário/agrícola de uso dos recursos naturais. Revista Internacional Interdisciplinar INTERthesis, Florianópolis, v. 1, n. 1, p. 1-55, jan. 2004. ISSN 18071384. Disponível em: <https://periodicos.ufsc.br/index. php/interthesis/article/view/604>. Acesso em: 23 abr. 2016

GOOLDMAN, David; SORJ, Bernardo; WILKINSON, John. Da lavoura às biotecnologias. Rio de Janeiro: Campus, 1990.

GUIBERT, Martine; BUHLER, Eve Anne; REQUIERDESJARDINS Denis. Entreprises agricoles et globalisation des espaces ruraux. Eclairages à partir de l'Argentine, du Brésil et de l'Uruguay. Géographie, Economie, Société, França, v. 17, p. 387-408, 2015.

HAESBAERT, Rogério. Des-territorialização e identidade: a rede "gaucha" no Nordeste. Niterói: EdU̧FF, 1997.

HARVEY, DAVID. Le nouvel impérialisme. Paris: Les Prairies Ordinaires, 2010

HAYTER, Roger; PATCHELL, J. Resource geography. In: WRIGHT, J. D. (Coord.). International encyclopedia of the social \& behavioral sciences. $2^{\mathrm{a}}$ ed. Oxford: Elsevier, 2015. v. 20 . p. 568-575.

HERVIEU, Bertrand. Les agriculteurs. Paris: Presses Universitaires de France, 1996.

PURSEIGLE, François. Sociologie des mondes agricoles. Paris: Armand Colin, 2013.

; PURSEIGLE, F. Des agricultures avec des agriculteurs, une nécessité pour l'Europe. Projet, AuzevilleTolosane, n. 321, p. 60-69, 2011-2012.

HIGGINS, Vaughan. et al. Neoliberalising rural environments. Journal of Rural Studies, Australia, n. 36 , p. 386-390, 2014

MACHADO, Lia Osorio. A fronteira agrícola na Amazônia Brasileira. Revista Brasileira de Geografia, Rio de Janeiro, v. 54, n. 2, p. 27-55, 1994.

MANN, Susan. A.; DICKINSON, James M. Obstáculos ao desenvolvimento da agricultura capitalista. Literatura Econômica, Rio de Janeiro, v. 9, n. 1, p. 7-26, fev.1987.

MARTINS, José de Souza. Fronteira: a degradação do outro nos confins do humano. São Paulo: Editora Contexto, 2009.

MARX, Karl. Rascunhos da carta à Vera Sassulitch de 1881. Raízes, Campina Grande, v. 24, n. 1-2, p. 110-123, jan./dez. 2005.

. A Chamada Acumulação Primitiva. In: MARX, K. O Capital: crítica da economia política- Livro I - v. 2. Rio de Janeiro: Bertrand Brasil, 1996, p. 828-883.

McMICHAEL Philip. A food regime genealogy. The Journal of Peasant Studies, Inglaterra, v. 36, p.139-169, 2009.

MORAES, Reginaldo C.; ARABE, Carlos Henrique G.; SILVA, Maité de Paula. As cidades cercam os campos: estudos sobre projeto nacional e desenvolvimento agrário na era da economia globalizada. São Paulo: Editora Unesp; Brasília: NEAD, 2006.
NAVARRO, Zander. O mundo rural no novo século (Um ensaio de interpretação). In: VIEIRA FILHO, J. E.; GASQUES, J.G. Agricultura e crescimento. Brasília: IPEA, 2016.

IBIAPABA NETTO. Você conhece o Mapito? Isto $\hat{E}$ Dinheiro, São Paulo, n. 632, 18 nov. 2009. Disponível em: http://www.istoedinheiro.com.br/noticias/189 VOCE+CONHECE+O+MAPITO. Consultado em 10/06/2011.

OUMA, Stefan. Situating global finance in the land rush debate: a critical review. Geoforum, [S.1], n. 57, p. 162-165, 2014

PESCHARD, Karine. Unexpected discontent: exploring new developments in Brazil's transgenics controversy. Canadian Journal of Development Studies/Revue canadienne d'études du développement, Inglaterra, v. 33, n. 3, 2012, p. 326-337, 2012.

PORTER, MICHAEL. L'avantage concurrentiel des nations. Paris: InterEditions, 1993

RAMOS, Pedro. Dimensões do agronegócio brasileiro: políticas, instituições e perspectivas. Brasília: NEADMDA, 2007.

REIS, Maria Rita. Propriedade intelectual, sementes e o sistemadecobrançaderoyaltiesimplementadoela Monsanto no Brasil [online]: portal MDA, 2005. Disponível em: www.http://portal.mda.gov.br/dotlrn/clubs/biossegurana/ contents/bug?page $=2 \&$ format $=$ table\&f state $=119 \&$ bug number $=31 \&$ orderby $=$ summary\%2Cdesc $\quad$ [Consultado em 22/04/2016].

RODRIGUES, Vera Lucia G. S. Urbanização e ruralidade: os condomínios e os conselhos de desenvolvimento municipal. Brasília: MDA, 2009

SABAI, Ernani Edvino. Panorama socioeconômico do agronegócio do oeste da Bahia, Barreiras. AIBA [online], 2015. Disponível em: http://aiba.org.br/wp-content/ uploads/2013/11/producao-e-destino-dos-graos-do-oesteda-bahia.pdf. Acesso em: 05 abril 2016.

SILVESTRO, Milton Luiz et al. Sucessão hereditária e reproducão social da agricultura familiar. Agricultura São Paulo, São Paulo, v. 50, n. 1, p. 11-24, 2003.

SOTO, Gustavo. No puedes comer dinero. In: El grano de arena: informativo semanal ATTAC. n. 457. Disponível em: http://www.archive.attac.org/attacinfoes/attacinfo457. pdf. Acesso em: 23 abr. 2016.

VEIGA, José Eli. Delimitando a agricultura familiar. Revista Reforma Agrária. Campinas, v. 25, maio/dez. 1995.

WANDERLEY, Maria de Nazareth Baude. Os estudos rurais no Brasil: as ciências sociais e as questões da sociedade. IN: ENCONTRO ANUAL DA ANPOCS, 33. 2009, Caxambu. Anais... Caxambu, 2009.

WINNER, Langdon. La baleine et le réacteur. À la recherche de limites au temps de la haute technologie. Paris: Descartes et Cie, 2002

WOODS, Michael. Rural.Londres: Routledge, 2011. 


\section{TECHNIQUE AND NATURE IN THE DEVELOPMENT OF "AGRIBUSINESS"}

\author{
Valter Lúcio de Oliveira \\ Ève Anne Bühler
}

If, in many economic sectors, the logic of capitalist accumulation has been implemented without facing major obstacles, in agriculture, on the contrary, important aspects related to its natural character have imposed significant limitations. Until the 1970's, for instance, the cerrado was not considered apt for the agricultural practice that is now practiced there. In the same way, advances of biotechnologies in cultivations have overcome and promise to overcome even more limitations that still persist. Based on these considerations, we intend to characterize the agriculture developed in Northeastern Brazil's cerrado and to analyze the relation that this region have with nature according to technique and capitalist accumulation. The consolidation of a neoliberal agriculture can be perceived in these regions in which the commoditization of nature is a prominent dimension in the process of incorporating new agricultural frontiers. This is supported by the discourse and the technicist practice of agents of the sector that aim to better control productive processes. In this dynamic, despise for native ecosystems and control of nature relying on technique are still fundamental elements in the discourse for attraction of settlers and investors to the area. These aspects will be discussed based on an empirical research that has been developed since 2011 in the region known as MAPITOBA (acronym of the states of Maranhão, Piauí, Tocantins and Bahia).

KEYwORDs: Agribusiness. Northeastern Brazil's cerrado. Business Agriculture

\section{TECHNIQUE ET NATURE DANS LE DÉVELOPPEMENT DE "L'AGRIBUSINESS"}

\author{
Valter Lúcio de Oliveira \\ Ève Anne Bühler
}

Si la logique capitaliste d'accumulation a eu lieu dans divers secteurs de l'économie sans être confrontée à de grands obstacles, en revanche dans l'agriculture d'importants aspects liés à son caractère naturel lui ont imposé des limitations importantes. Jusque dans les années 1970, par exemple, le cerrado n'était pas considéré favorable au type d'agriculture qui y est pratiqué aujourd'hui. Il en est de même des progrès de la biotechnologie dans les campagnes qui ont déjà dépassé et promettent d'aller au-delà de certaines limitations qui persistent encore. Partant de telles considérations, notre intention est de caractériser l'agriculture développée dans les cerrados du nord-est et d'analyser la relation établie avec la nature en nous basant sur la technique et l'accumulation capitaliste. Dans ces régions nous pouvons constater une consolidation de l'agriculture néolibérale où la marchandisation de la nature a une dimension évidente dans le processus de constitution de nouvelles frontières agricoles. Elle se base sur le discours et la pratique des agents techniques du secteur qui cherchent à mieux dominer les processus productifs. Dans cette dynamique, le mépris pour les écosystèmes indigènes et le contrôle de la nature à partir de la technique sont encore des éléments fondamentaux dans le discours fait pour attirer les colons et les investisseurs dans le secteur. Ces aspects seront traités sur la base d'une recherche empirique menée depuis 2011 dans une région connue sous la dénomination de MAPITOBA (Maranhao, Piaui, Tocantins et Bahia).

Mots-CLÉs: Agribusiness. Cerrados du Nord-est. Affaires Agriculture.

Valter Lúcio de Oliveira - Doutor em Ciências Sociais em Desenvolvimento e Agricultura. Professor do Departamento de Sociologia e Metodologia das Ciências Sociais. Universidade Federal Fluminense, vinculado aos Programas de Pós-Graduação em Sociologia (PPGS) e Sociologia e Direito (PPGSD) da mesma Universidade. Integra o Núcleo de Pesquisa Fronteiras e Transformações das Práticas Estatais e Políticas, desenvolvendo pesquisas na área de Sociologia Rural e Ambiental com foco nas agriculturas empresariais e nos efeitos dos grandes empreendimentos sobre o espaço rural. Publicações recentes: $O$ assentamento como terra de missão: religião e processos de territorialização dos sem-terra no Rio Grande do Sul. Século XXI - Revista de Ciências Sociais, v. 04, p. 226-259, 2014; La localisation des entreprises agricoles dans l ouest de l État de Bahia. Etudes Rurales, v. 191, p. 45, 2013; The location of agricultural firms in the Western Bahia Region of Brazil. Etudes Rurales, v. 191, p. 91-113-113, 2013.

Eve Anne Bühler - Doutora em Geografia na especialidade ESSOR (Espaços, Sociedades Rurais e Lógicas Econômicas). Professora do Departamento de Geografia da Universidade Federal do Rio de Janeiro. Integra o Núcleo de Pesquisa NUCLAMB (Núcleo de Estudos Geoambientais), desenvolvendo pesquisas na área de Geografia Agrária e Ambiental, com foco nas agriculturas empresariais e no rural metropolitano. Publicações recentes: Funciones del recurso suelo y formas empresariales de producir. Avance del capitalismo agrario en Argentina y Brasil. Revista de Ciencias Sociales (Montevideo), v. 29, p. 59-80, 2016; Arènes et ressources $d u$ droit au village: les ressorts de l'émancipation dans les campagnes occidentales au 21 ème siècle. justice spatiale - spatial justice, v. 7, p. 1-27, 2015; Entreprises agricoles et globalisation des espaces ruraux. Éclairages à partir de l’Argentine, du Brésil et de l’Uruguay. Géographie, Economie, Société, v. 17, p. 387408, 2015; Expansion de l'agribusiness sucro-énergétique au Brésil et modèles de développement: le cas de la région de Dourados (État du Mato Grosso do Sul). Géographie, Economie, Société, v. 17, p. 459-483, 2015. 